UDC 620.193:620.199

\author{
A. Kityk ${ }^{a}$, V. Protsenko ${ }^{a}, V$. Pavlik $^{b}, M$. Boča $^{b}$
}

\title{
CORROSION RESISTANCE OF AISI 304 AND AISI 316 STAINLESS STEELS IN A SOLAR SALT USED IN CONCENTRATED SOLAR POWER PLANTS: THE EFFECT OF NaCl IMPURITIES
}

\author{
${ }^{a}$ Ukrainian State University of Chemical Technology, Dnipro, Ukraine \\ ${ }^{b}$ Institute of Inorganic Chemistry, Slovak Academy of Sciences, Bratislava, Slovakia
}

\begin{abstract}
High-temperature corrosion of stainless steels AISI 316 and AISI 304 in a molten «solar salt» used as a heat transfer fluid in concentrating solar power $\left(60 \mathrm{wt} \% \mathrm{NaNO}_{3}\right.$ and 40 wt.\% $\mathrm{KNO}_{3}$ ) was investigated at the temperature of $550^{\circ} \mathrm{C}$. It was shown that the corrosion rate is influenced by the composition of stainless steel and the presence of impurities $\mathrm{NaCl}$ in the solar salt. With an increase in the content of sodium chloride impurity in the solar salt, the corrosion rate of both stainless steels increases. The corrosion resistance to the destruction of stainless steels AISI 316 and AISI 304 is provided by the formation of $(\mathrm{Cr}, \mathrm{Fe})_{2} \mathrm{O}_{3}$ oxide film on the surface of the samples. Thus AISI 304 stainless steel with chromium content of ca. $20 \%$ shows higher corrosion resistance in the solar salt than AISI 316 stainless steel with lower chromium content (ca. 18\%). It is known that AISI 304 stainless steel additionally contains molybdenum and a higher content of nickel. The presence of these transition metals in the composition of stainless steel also affects the formation of a protective oxide film that prevents further corrosion damage of steel samples.
\end{abstract}

Keywords: solar salt, $\mathrm{NaCl}$ impurity, corrosion, stainless steel, protective oxide film, concentrating solar power.

DOI: $10.32434 / 0321-4095-2019-124-3-123-131$

\section{Introduction}

The search for «green» resources for the production of electrical energy is one of the main tasks of up-to-date science. An important advance in solving this problem was achieved by the development of concentrating solar plants (CSP) which are based on the conversion of sunlight into electricity [1]. CSPs use mirrors to concentrate the energy from the sun to drive traditional steam turbines or engines that create electricity [2]. The thermal energy concentrated in a $C S P$ can be stored and further used to produce electricity when it is needed, at any hour of the day or night. Over 1,800 megawatts of electricity are generated in the United States and other countries at the CSPS [3]. In general, CSP manufacturing processes are divided into three groups: parabolic trough lines, dish concentrators and power tower technologies [4]. It should be noted that a very important technological issue in the creation of CSPS is a correct selection of the optimal composition of heat transfer fluid and structural materials that would not be corroded in a hightemperature corrosive medium $[5,6]$.

Commonly, cheap and affordable metals and alloys with relatively high corrosion resistance are used as construction materials for CSPs, among them $\mathrm{Ni}$ alloys and stainless steels appear to be the most promising. High-temperature nickel based alloys can appreciably increase stress-strain properties and improve corrosion resistance at elevated temperatures; however, a high cost of nickel based alloys, which are nearly four times more expensive than iron based steels [2], impedes their wide application in CSPs. Thus, the use of stainless steels seem to be a logical choice, since they form a protective adherent $\mathrm{Cr}_{2} \mathrm{O}_{3}$ film on the surface at high temperatures [1,2] to reliably prevent corrosion damage.

The mostly used heat transfer fluid is composed of 60 wt. $\% \mathrm{NaNO}_{3}$ and 40 wt.\% $\mathrm{KNO}_{3}$ [7]; it is called «solar salt». This mixture melts at $223^{\circ} \mathrm{C}$, is

(C) A. Kityk, V. Protsenko, V. Pavlik, M. Boča, 2019

Corrosion resistance of AISI 304 and AISI 316 stainless steels in a solar salt used in concentrated solar power plants: the effect of $\mathrm{NaCl}$ impurities 
thermally stable up to about $600^{\circ} \mathrm{C}$ and offers a favorable combination of high density, low vapor pressure, moderate specific heat, low chemical reactivity and low cost [8]. Molten nitrate mixture also satisfies other important requirements for solar plants: high thermal conductivity, diffusivity and a low heat loss coefficient [9]. However, the commercial product of the solar salt often contains impurities of $\mathrm{NaCl}$ up to $5 \mathrm{wt} . \%$. Sodium chloride as an impurity in the solar salt can significantly increase the rate of corrosion of CSP structural materials. This influence can be especially strong at high temperatures [10]. Evidently, successful development and fail-proof maintenance of CSPS are not possible without the data on the corrosion stability of construction materials in the solar salt, including in the presence of contaminants.

A few works dealing with the influence of chloride ions on the rate of corrosion in molten salts do not cover the cheapest and often used construction materials and do not give a comparative characterization of the corrosive behavior of these materials in the presence and absence of chloride ions [11-13]. Also, the previous studies do not cover the operation temperature conditions typical of CSPS and the real amounts of impurities in commercial solar salts. Therefore, the purpose of this work was to investigate the corrosive behavior of two kinds of stainless steel, AISI 304 and AISI 316, in a solar salt containing sodium chloride impurity at a temperature of $550^{\circ} \mathrm{C}$, which corresponds to the conditions of real solar salt operation in CSPS.

\section{Materials and methods}

Preparation of solar salt and characterization of stainless steel

The solar salt was prepared by mixing of two components, $\mathrm{NaNO}_{3}$ and $\mathrm{KNO}_{3}$, in the ratio of 60 wt.\% and 40 wt.\%, respectively. The $\mathrm{NaCl}$ impurity was directly added to the prepared solar salt; its content in the mixture was 2 or $5 \mathrm{wt} . \%$.

Two kinds of stainless steel, AISI 304 and AISI 316 , were chosen for the investigation, their chemical compositions are given in Table 1 . Steel samples used in corrosion tests had dimensions of $50 \times 20 \times 5 \mathrm{~mm}$. Before tests, all samples were polished with 600 grit black silicon carbide abrasive papers and washed with distilled water and acetone.

\section{Electrochemical experiments}

In order to determine the main corrosion characteristics of AISI 304 and AISI 316 stainless steels in the solar salt, open circuit potential (OCP) and linear polarization resistance (LPR) were measured.

OCP and LPR measurements were carried out using a common three-electrode cell and the potentiostat Metrohm Autolab PGSTAT128N (Netherlands) controlled by a personal computer with Autolab NOVA software. The samples of AISI 304 and AISI 316 stainless steels were the working electrodes, platinum wire $(\varnothing 0.5 \mathrm{~mm})$ was the reference electrode and the whole graphite crucible served as the counter electrode.

The OCP was recorded using a platinum wire as a reference electrode. The LPR was measured from initial potential $-0.1 \mathrm{~V}$ to final potential $0.1 \mathrm{~V}$ with the scan rate of $1 \mathrm{mV} \mathrm{s}^{-1}$. The cell construction and equipment for voltammetric studies are presented in Fig. 1.

The temperature in all experiments was $550^{\circ} \mathrm{C}$. Temperature controller was Clasic Clare 4.0 (co. Clasic, Cz.) calibrated using the thermocouple $\mathrm{Pt}-\mathrm{PtRh} 10$.

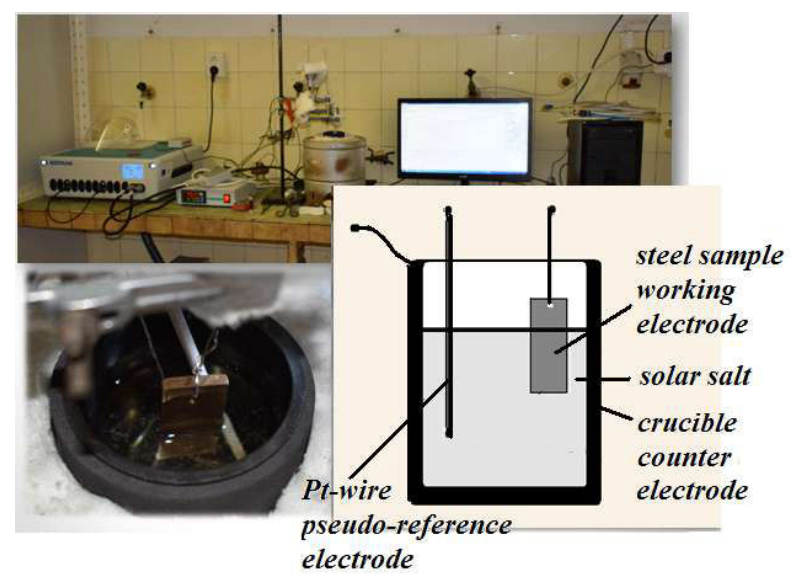

Fig. 1. Construction of electrochemical cell for OCP and LPR measurements

SEM study

Scanning electron microscopy (SEM) (JEOL7600F, Japan, Co lamp) in combination with

Table 1

Chemical compositions of the stainless steel samples

\begin{tabular}{c|c|c|c|c|c|c|c}
\hline \multirow{2}{*}{$\begin{array}{c}\text { Stainless } \\
\text { steel }\end{array}$} & \multicolumn{7}{c}{ Content, wt.\% } \\
\cline { 2 - 8 } & $\mathrm{C}$ & $\mathrm{Si}$ & $\mathrm{Mn}$ & $\mathrm{Cr}$ & $\mathrm{Mo}$ & $\mathrm{Ni}$ & $\mathrm{Fe}$ \\
\hline AISI 304 & 0.08 & 1.00 & 2.00 & $17.50 \div 20.00$ & - & $8.00 \div 10.15$ & the rest \\
\hline AISI 316 & 0.08 & 1.00 & 2.00 & $16.00 \div 18.00$ & 2.50 & $10.00 \div 14.00$ & the rest \\
\hline
\end{tabular}


electron dispersive spectroscopy (EDS) (Oxford Instruments Ltd., UK) were used for the observation of surface and cross-sectional morphology and compositions. Electron gun voltage was $15 \mathrm{kV}$ to ensure sufficient extraction energy and quantify chemical composition; Co standard was used before measurement. The samples for microstructural observation were prepared via standard metallographic methods such as grinding and mechanical polishing. No additional etching was used.

\section{Results and discussion}

High-temperature corrosion behavior of stainless steels AISI 304 and AISI 316 in the solar salt was estimated by measuring open-circuit potential and determining linear polarization resistance of the corroding samples.

The dependence of open circuit potential on exposure time is shown in Fig. 2 at different concentration of $\mathrm{NaCl}$ admixture in the melted solar salt.

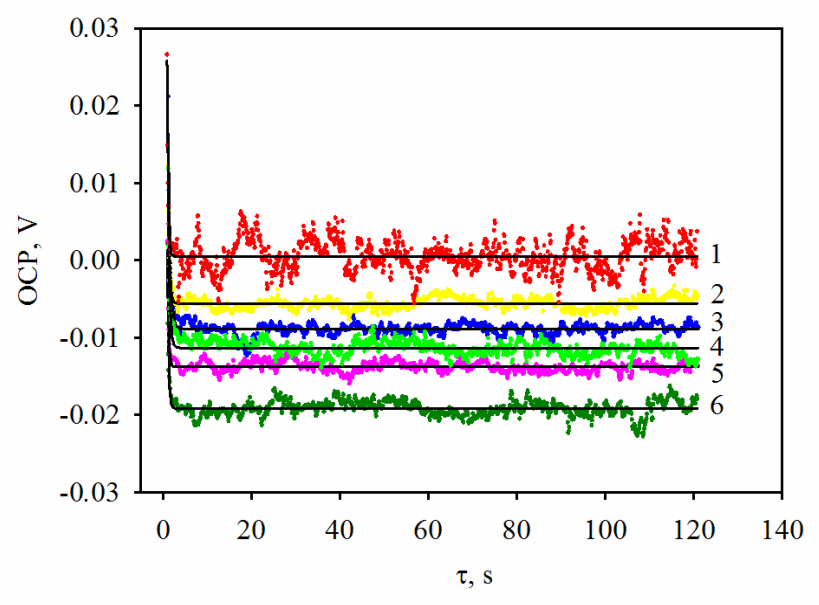

Fig. 2. Dependences of OCP on time at different sodium chloride content in the solar salt at $550^{\circ} \mathrm{C}$ :

(1), (2) and (3) - AISI 304; (4), (5) and (6) - AISI 316;

(1) and (4) -0 wt.\% NaCl; (2) and (5) -2 wt.\% NaCl;

(3) and (6) -5 wt. $\% \mathrm{NaCl}$

As can be seen, the OCP abruptly changes during first few seconds after immersion of the sample in the solar salt and then reaches an approximately constant value demonstrating moderate oscillations. It should be noted that OCP depends not only on the type of stainless steel but also on $\mathrm{NaCl}$ concentration. AISI 316 stainless steel exhibits more negative OCP values than AISI 304, other conditions being equal. This may indicate a lesser resistance of AISI 316 to high-temperature corrosion in the solar salt. With an increase in the sodium chloride content in the solar salt the OCP values shift to the more negative region for both steels which can be associated with a decrease in corrosion resistance at increasing $\mathrm{Cl}^{-}$ions content.

The quantitative characteristics of hightemperature corrosion of AISI 304 and AISI 316 stainless steels in the solar salt were estimated by LPR measurements. Tafel plots for AISI 304 and AISI 316 samples in the solar salt without and with $\mathrm{NaCl}$ admixtures are shown in Fig. 3. The presented data indicate that there are linear regions in the polarization dependences plotted in E vs. $\log \mathrm{i}$ coordinates; the linearity is distorted only in the initial segments of the polarization dependences near to the OCP.

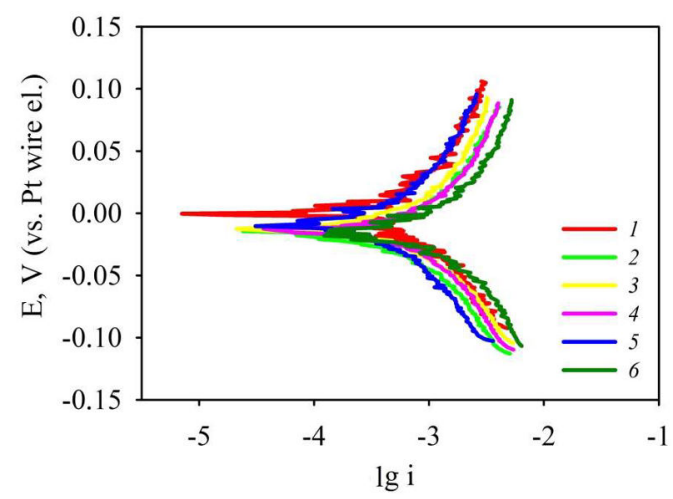

Fig. 3. Tafel plots for AISI 304 and AISI 316 samples in the solar salt without and with $\mathrm{NaCl}$ admixtures at $550^{\circ} \mathrm{C}$ :

(1), (2) and (3) - AISI 304; (4), (5) and (6) - AISI 316;

(1) and (4) -0 wt. $\% \mathrm{NaCl}$; (2) and (5) -2 wt. $\% \mathrm{NaCl}$;

(3) and (6) -5 wt.\% NaCl

The linearity of the sections in E vs. lgi plots testifies that they obey Tafel equation:

$\eta=a+b \cdot \lg i$

where $\eta$ is the overvoltage $\left(\eta=\left(E-E_{\text {eq }}\right), E\right.$ is the current electrode potential; $\mathrm{E}_{\mathrm{eq}}$ is the equilibrium electrode potential); $\mathrm{a}$ and $\mathrm{b}$ are the Tafel constants.

It should be observed that the values in Tafel equation are positive and negative for the anodic and cathodic processes, respectively. For the sake of simplicity, we show further only the absolute values disregarding the differences in the positiveness or negativeness of quantities.

Since the values of equilibrium electrode potential are not strictly known both for the cathodic electrode reaction and for the anodic one, Eq. (1) can be rewritten in the following form: 
$E=\left(a+E_{e q}\right)+b \cdot \lg i=$ const $+b \cdot \lg i$.

This expression justifies the legitimacy of the treatment of experimental results in E vs. $\lg \mathrm{i}$ coordinates (but not in $\eta$ vs. lgi).

The values of Tafel slopes, $b_{a}$ and $b_{c}$, for the anodic and cathodic reaction, respectively, were determined from the obtained data (Table 2).

The corrosion current density, $\mathrm{i}_{\text {corr }}$, is related to the polarization resistance, $\mathrm{R}_{\mathrm{pol}}$ (in $\mathrm{Ohm} \mathrm{cm}^{-2}$ ), by the Stern-Geary coefficient, B, as follows [14]:

$$
\begin{aligned}
& \mathrm{B}=\frac{\mathrm{b}_{\mathrm{a}} \cdot \mathrm{b}_{\mathrm{c}}}{2.303 \cdot\left(\mathrm{b}_{\mathrm{a}}+\mathrm{b}_{\mathrm{c}}\right)}, \\
& \mathrm{i}_{\text {corr }}=\frac{\mathrm{B}}{\mathrm{R}_{\mathrm{pol}}}=\frac{1}{\mathrm{R}_{\text {pol }}} \cdot \frac{\mathrm{b}_{\mathrm{a}} \cdot \mathrm{b}_{\mathrm{c}}}{2.303 \cdot\left(\mathrm{b}_{\mathrm{a}}+\mathrm{b}_{\mathrm{c}}\right)},
\end{aligned}
$$

where $\mathrm{i}_{\text {corr }}$ and $\mathrm{B}$ are given in $\mathrm{A} \mathrm{cm}{ }^{-2}$ and $\mathrm{V}$, respectively; $b_{a}$ and $b_{c}$ are the anodic and cathodic Tafel slopes (in $\mathrm{V} \mathrm{dec}{ }^{-1}$ ).

The polarization resistance $\left(\mathrm{R}_{\mathrm{pol}}\right)$ was determined as the slope of the potential (E) vs. current density (i) dependences at $\mathrm{i}=0$ :

$$
R_{p o l}=\left(\frac{\partial \Delta E}{\partial i}\right)_{i=0, d E / d t \rightarrow 0},
$$

where $\Delta \mathrm{E}=\mathrm{E}-\mathrm{E}_{\text {corr }}$ and $\mathrm{E}_{\text {corr }}$ is the OCP.

Finally, the corrosion rate, CR (in mm year ${ }^{-1}$ ), was calculated using the Faraday equation in the form:

$\mathrm{CR}=\mathrm{k} \cdot \frac{\mathrm{i}_{\text {corr }}}{\mathrm{d}} \cdot \mathrm{EW}$

where $\mathrm{k}$ is a conversion factor $\left(3.27 \cdot 10^{6}\right.$ $\left.\mathrm{mm} \cdot \mathrm{g} \cdot \mathrm{A}^{-1} \cdot \mathrm{cm}^{-1} \cdot \mathrm{year}^{-1}\right), \mathrm{i}_{\text {corr }}$ is the corrosion current density in $\mathrm{mA} \mathrm{cm}^{-2}$ (calculated from the measurements of $R_{p o l}$ ), $d$ is the density and EW is the equivalent weight.

All calculated parameters characterizing the corrosion behavior of AISI 304 and AISI 316 stainless steels in the solar salt without and with $\mathrm{NaCl}$ admixtures are summarized in Table 2 .

As can be seen from Table 2, corrosion characteristics depend on both the nature of stainless steel and $\mathrm{NaCl}$ content in the solar salt. At the same time, the values of Tafel slopes (both cathodic and

Table 2

\begin{tabular}{|c|c|c|c|c|c|c|c|}
\hline \multirow{2}{*}{$\begin{array}{l}\text { Sample } \\
\text { material }\end{array}$} & \multirow{2}{*}{$\begin{array}{l}\text { Content of } \\
\mathrm{NaCl} \text {, wt.\% }\end{array}$} & \multicolumn{6}{|c|}{ Corrosion parameters } \\
\hline & & $E_{\text {corr }}, V$ & $b_{a}, V d e c^{-1}$ & $b_{c}, V d e c^{-1}$ & $\mathrm{i}_{\text {corr }}, \mu \mathrm{A} \mathrm{cm}^{-}$ & $\mathrm{R}_{\mathrm{pol}}, \Omega \mathrm{cm}^{-2}$ & CR, mm year ${ }^{-1}$ \\
\hline \multirow{3}{*}{ AISI 304} & 0 & -0.008 & 0.122 & 0.093 & 27.51 & 55.296 & 0.345 \\
\hline & 2 & -0.010 & 0.133 & 0.100 & 33.59 & 47.342 & 0.420 \\
\hline & 5 & -0.014 & 0.138 & 0.103 & 40.73 & 44.232 & 0.506 \\
\hline \multirow{3}{*}{ AISI 316} & 0 & -0.019 & 0.115 & 0.097 & 35.83 & 46.792 & 0.429 \\
\hline & 2 & -0.021 & 0.128 & 0.106 & 40.55 & 44.337 & 0.499 \\
\hline & 5 & -0.022 & 0.138 & 0.111 & 47.75 & 40.689 & 0.586 \\
\hline
\end{tabular}

Calculated parameters characterizing the corrosion behavior of AISI 304 and AISI 316 stainless steels in the solar salt without and with $\mathrm{NaCl}$ admixtures
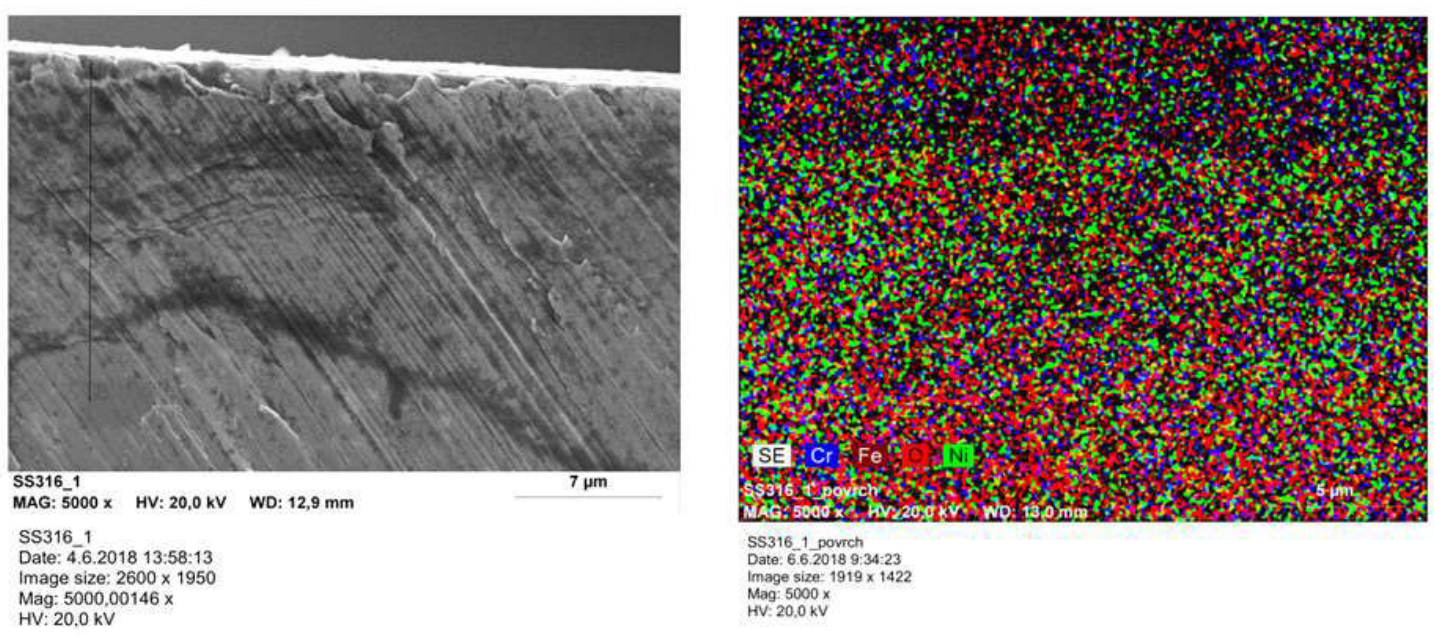

Fig. 4. SEM image from cross-section and element map of AISI 316 sample after immersion in the solar salt without $\mathrm{NaCl}$ 

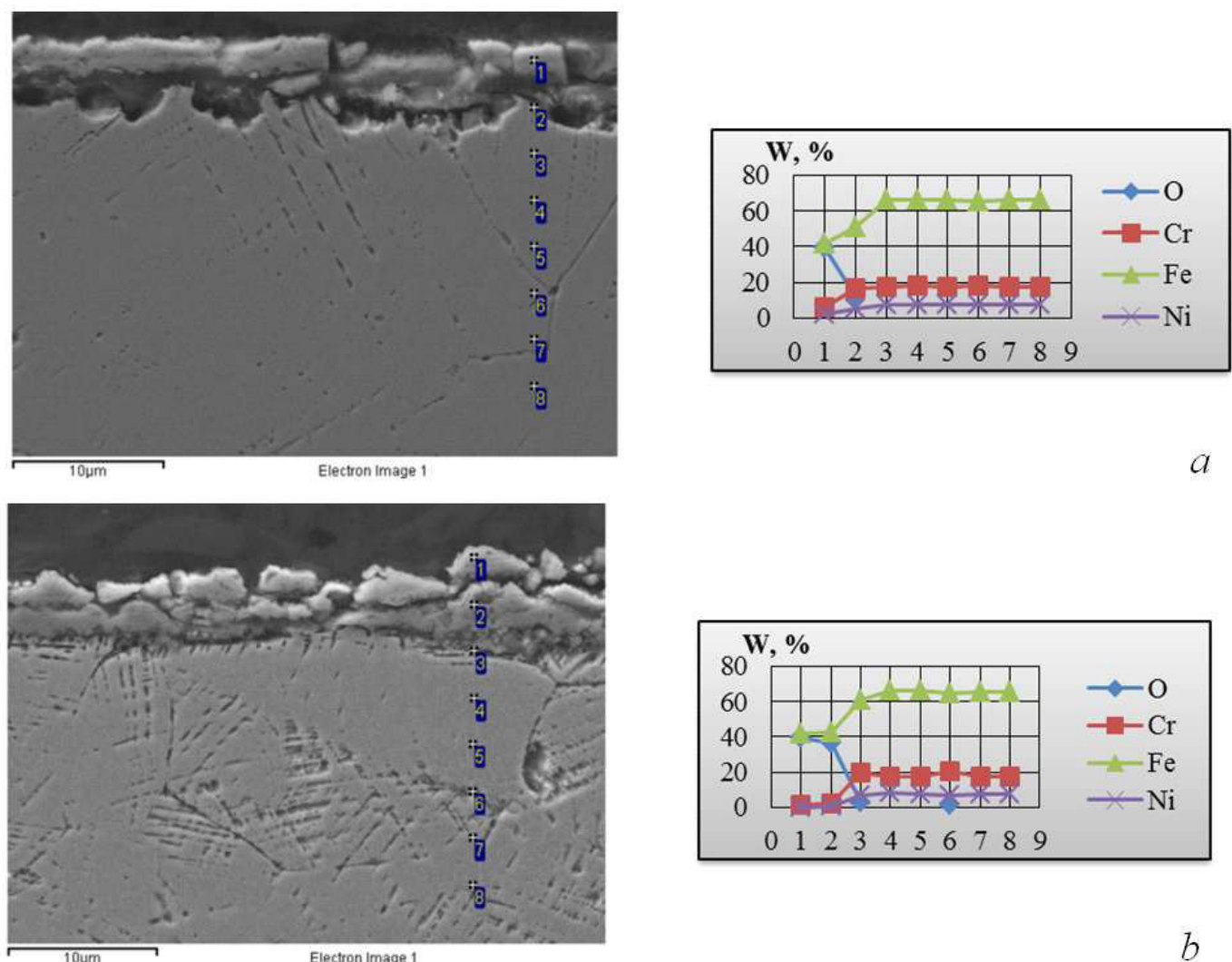

$a$

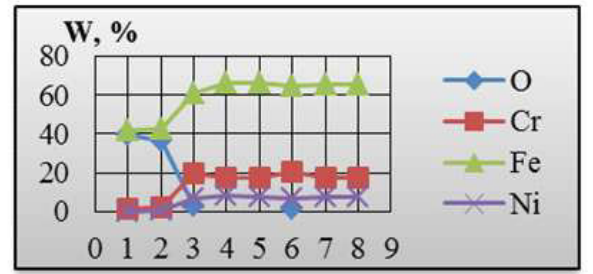

$b$
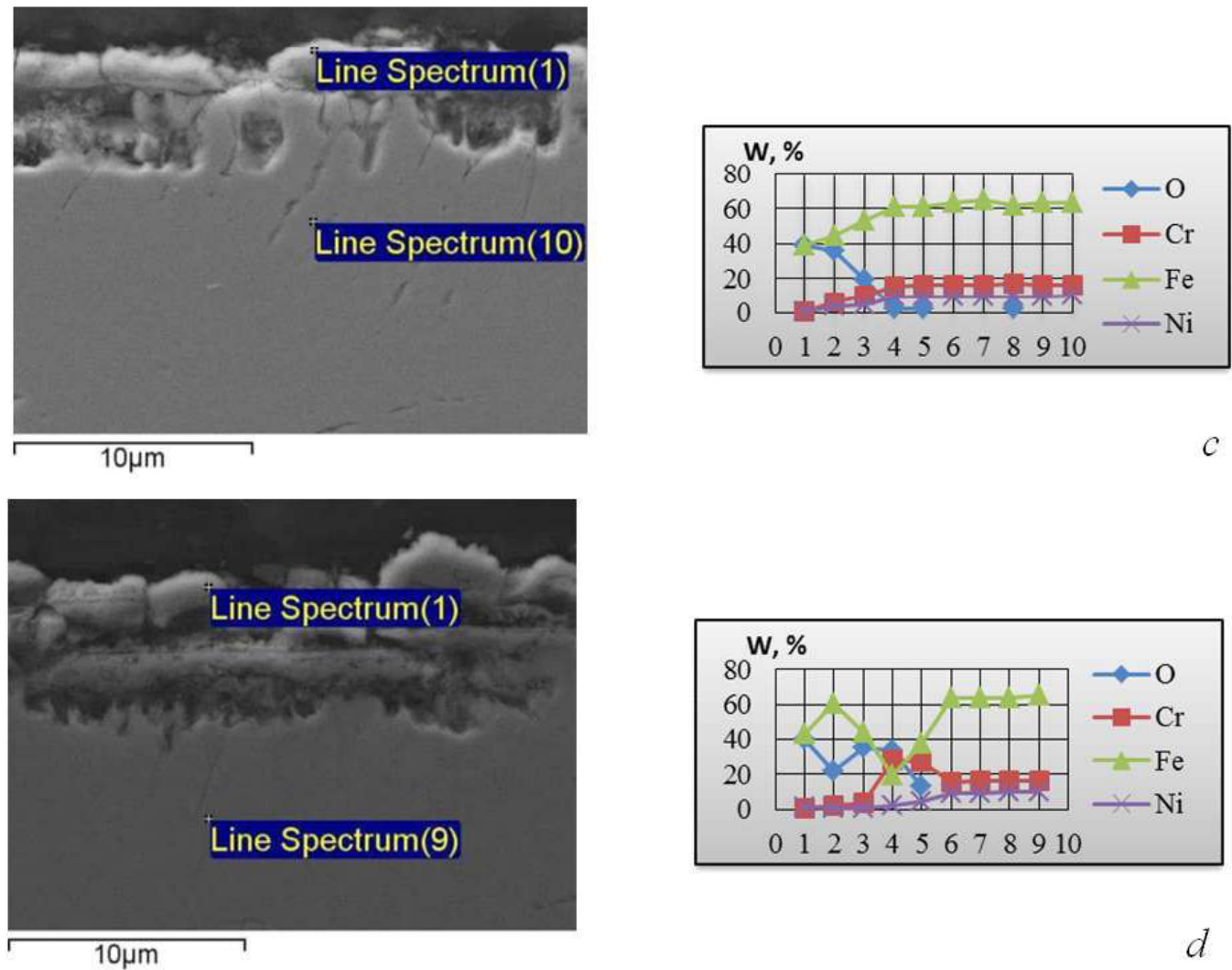

Fig. 5. SEM images from cross-section samples of AISI 304 (a - solar salt (ss) +2 wt. $\%, \mathrm{~b}-\mathrm{ss}+5$ wt. $\%$ ) and AISI 316 $(\mathrm{c}-\mathrm{ss}+2 \mathrm{wt} . \%, \mathrm{~d}-\mathrm{ss}+5 \mathrm{wt} . \%)$ after corrosion process with detailed elemental analysis 

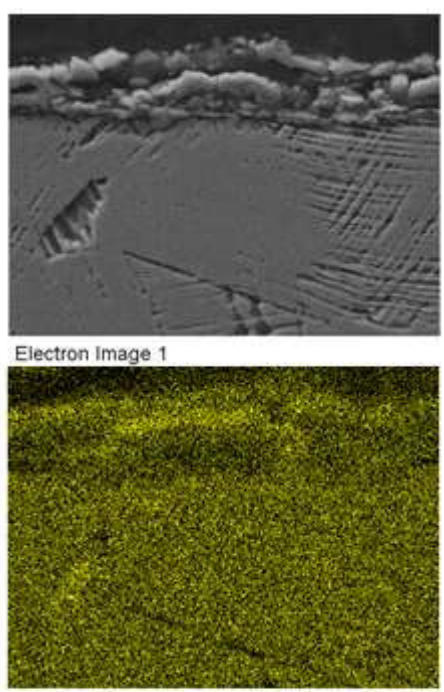

Ska1

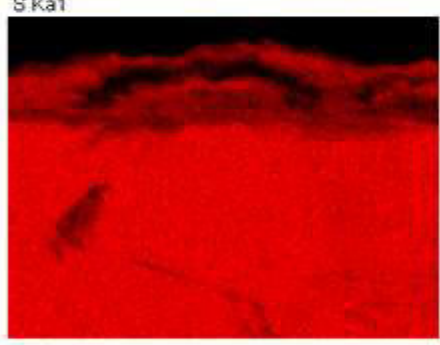

Fe Ka1

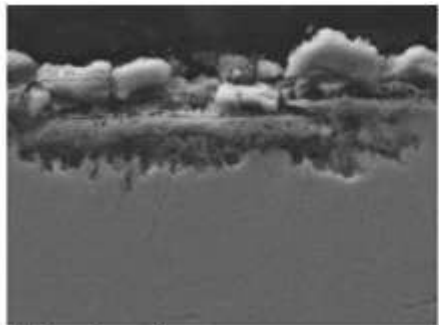

Electron Image 1

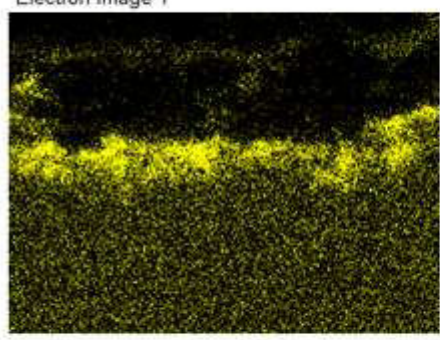

SKa1

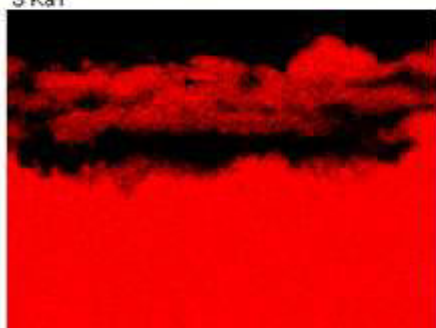

FeKa1
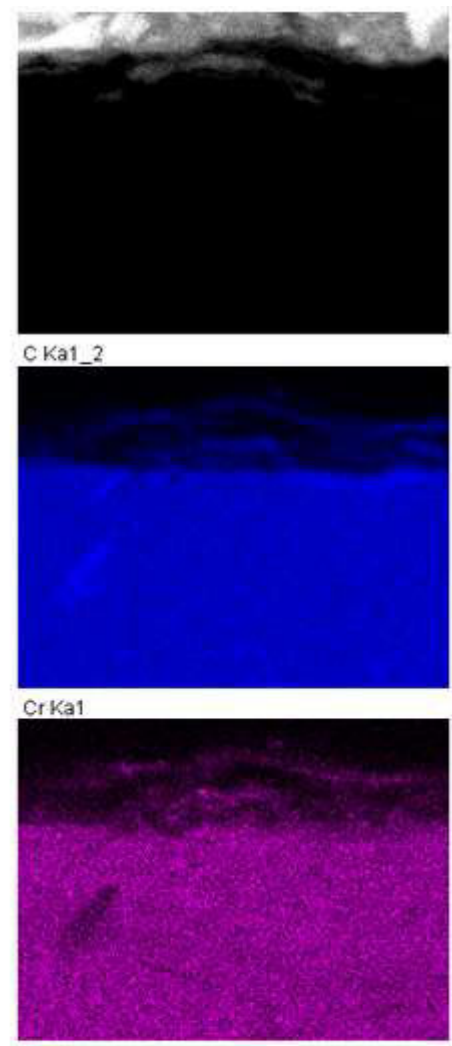

Ni Ka1

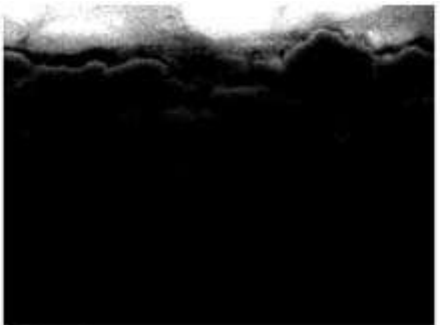

CKa1_2
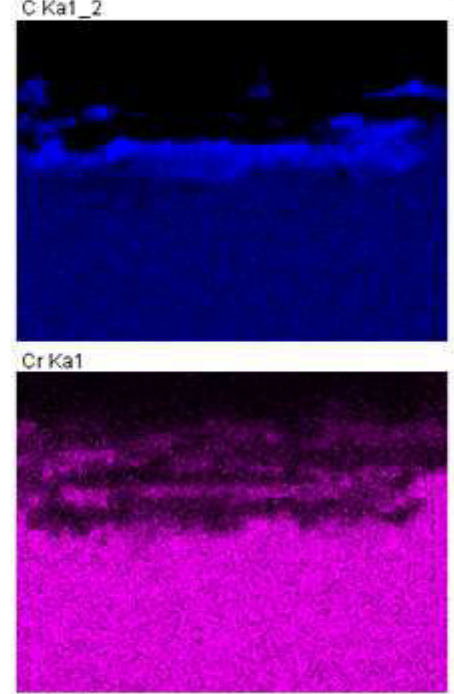

NiKa1

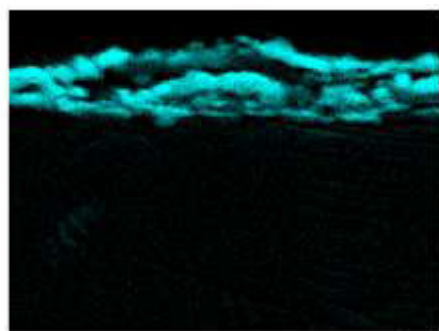

OKa1

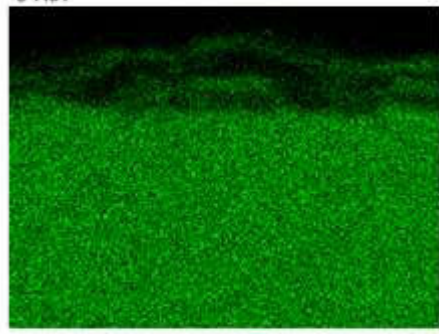

Mn Kat

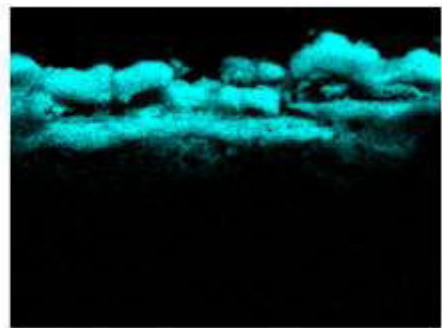

OKa1

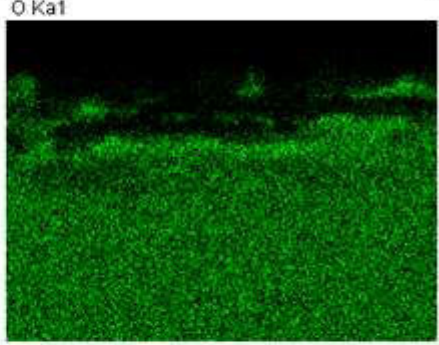

Mn Ka1

Fig. 6. Element maps for stainless steels AISI 304 (a) and AISI 316 (b) with corrosion products after immersion in the solar salt with the addition of $5 \% \mathrm{NaCl}$ 
anodic ones) do not differ substantially for AISI 304 and AISI 316 stainless steels at various $\mathrm{NaCl}$ content in the electrolyte indicating that the mechanism of electrochemical reaction remains unaltered.

Stainless steel AISI 316 exhibits lower polarization resistances and hence higher corrosion currents and corrosion rates than AISI 304 at a constant concentration of sodium chloride impurity. Thus, the corrosion resistance of AISI 304 stainless steel in the solar salt is better.

As concerns the effect of $\mathrm{NaCl}$ content, the corrosion process appreciably accelerates when the concentration of the impurity increases. For instance, the corrosion rates of AISI 304 and AISI 316 stainless steels are respectively 1.47 and 1.37 times higher at the concentration of $\mathrm{NaCl}$ impurity of $5 \%$ than in the «pure» solar salt.

Since the stainless steels under study are multicomponent alloys and the addition of $\mathrm{NaCl}$ may selectively affect the corrosion rates of their individual constituents, cross-section analysis was carried out and elements maps were obtained for the steels samples exposed to corrosive attack in the solar salt (Figs. 4,5,6).

Fig. 4 and 5 demonstrate that the hot-spot corrosion occurs in the solar salt without the admixture of $\mathrm{NaCl}$, whereas the intercrystalline corrosion is observed in the medium containing sodium chloride impurity.

Fig. 5 clearly shows the zone of transition from the base steel material to corrosion products. In addition to cross-section SEM images, this transition is also indicated by a change in the composition of samples: the oxygen content significantly increases and a slight decrease in the chromium and iron content is observed in zones with corrosion products, indicating the formation of oxide films containing these metals in oxides form.

The element maps also confirm the presence of a large amount of oxygen in the surface layer with corrosion products. It should be noted that the element maps allow establishing a noticeable difference in the composition of the surface layer of two stainless steels AISI 316 and AISI 304. It is noticeable that there is a difference in the chromium content in the surface layer of two stainless steels under consideration: chromium concentration in corrosion products layer is appreciably higher for AISI 304 than for AISI 316 (Fig. 5). Also, Fig. 5 shows that much deeper degradation can be seen for AISI 316 sample that accompanied by the exfoliation of iron oxide layers from the metal surface.

Thus the difference in corrosion rates of AISI 316 and AISI 304 can be explained by the fact that these two stainless steels have different compositions. Obviously, the different chromium content in the steel $2 \mathrm{~s}$ composition causes the difference in the corrosion resistance of metal samples in the solar salt. AISI 304 stainless steel with chromium content of ca. $20 \%$ exhibits a higher corrosion resistance in the solar salt than AISI 316 stainless steel with lower chromium content (ca. 18\%). AISI 304 stainless steel additionally contains molybdenum and a higher content of nickel. The presence of these transition metals in the composition of stainless steel ensures the formation of a protective oxide film that prevents further corrosion damage of steel samples.

At high-temperature corrosion of steels AISI 316 and AISI 304, a layer of $(\mathrm{Cr}, \mathrm{Fe})_{2} \mathrm{O}_{3}$ oxides is formed on the surface of the samples. As a result, the content of chromium decreases and the formation of $\mathrm{Fe}_{2} \mathrm{O}_{3}$ layer is observed, outer layer of corrosion products being represented mainly by $\mathrm{NaFeO}_{2}$. The effect of sodium chloride impurity on the corrosion rate of stainless steel can be explained by the formation of iron chloride below the oxide layer. Due to the relatively high volatility of iron chloride, a permanent exfoliation of the oxide layer occurs. Obviously, this is the reason for the increase in corrosion rate in the presence of sodium chloride impurity in the solar salt.

\section{Conclusions}

The rate of high-temperature corrosion of stainless steel in the solar salt depends on the nature of stainless steel and the amount of sodium chloride impurity. It is shown that stainless steel AISI 304 with higher chromium content is characterized by a higher corrosion resistance than AISI 316. Corrosion resistance in this case is due to the formation of a stable $(\mathrm{Cr}, \mathrm{Fe})_{2} \mathrm{O}_{3}$ oxide film.

\section{Acknowledgments}

This research was supported by National Scholarship Program financed by Slovak Republic and by Ministry of Education and Science of Ukraine (registration number 0119U002001). We thank our colleagues from Institute of Inorganic Chemistry, Slovak Academy of Sciences for successful research cooperation.

\section{REFERENCES}

1. Concentrated solar power plants: review and design methodology / H.L. Zhang, J. Baeyens, J. Degreve, G. Caceres // Renewable and Sustainable Energy Reviews. - 2013. - Vol.22. P.466-481.

2. Heat transfer fluids for concentrating solar power systems - a review / Vignarooban K., Xu Xinhai, Arvay A., Hsu K., 
Kannan A.M. // Applied Energy. - 2015. - Vol.146. - P.383396.

3. Moser M., Trieb F., Fichter T. Potential of concentrating solar power plants for the combined production of water and electricity in MENA countries // Journal of Sustainable Development of Energy, Water and Environment Systems. 2013. - Vol.1. - No. 2. - P.122-140.

4. Historical development of concentrating solar power technologies to generate clean electricity efficiently - a review / D.A. Baharoon, H.A. Rahman, W.Z.W. Omar, S.O. Fadhl // Renewable and Sustainable Energy Reviews. - 2015. - Vol.41. - P.996-1027.

5. Corrosion effects between molten salts and thermal storage material for concentrated solar power plants / Guillot S., Faik A., Rakhmatullin A., Lambert J., Veron E., Echegut P., Bessada C., Calvet N., Py X. // Applied Energy. - 2012. - Vol.94. - P.174181.

6. Tian Y., Zhao C.Y. A review of solar collectors and thermal energy storage in solar thermal applications // Applied Energy. - 2013. - Vol.104. - P.538-553.

7. Liu M., Saman W., Bruno F. Review on storage materials and thermal performance enhancement techniques for high temperature phase change thermal storage systems // Renewable and Sustainable Energy Reviews. - 2012. - Vol.16. - P.21182132.

8. Engineering aspects of a molten salt heat transfer fluid in at rough solar field / Kearney D., Kelly B., Herrmann U., Cable R., Pacheco J., Mahoney R., Price H., Blake D., Nava P., Potrovitza N. // Energy. - 2004. - Vol.29. - No. 5-6. - P.861870.

9. Kolb G.J. Economic evaluation of solar-only and hybrid power towers using molten salt technology // Solar Energy. 1998. - Vol.62. - No. 1. - P.51-61.

10. Singh I.B., Sen U. The effect of $\mathrm{NaCl}$ addition on the corrosion of mild steel in $\mathrm{NaNO}_{3}$ melt // Corrosion Science. 1993. - Vol.34. - No. 10. - P.1733-1742.

11. Fernandez A.G., Lasanta M.I., Perez F.J. Molten salt corrosion of stainless steels and low-Cr steel in CSP plants // Oxidation of Metals. - 2012. - Vol.78. - P.329-348.

12. Corrosion of stainless steels and low-Cr steel in molten $\mathrm{Ca}\left(\mathrm{NO}_{3}\right)_{2}-\mathrm{NaNO}_{3}-\mathrm{KNO}_{3}$ eutectic salt for direct energy storage in CSP plants / A.G. Fernandez, H. Galleguillos, E.Fuentealba, F.J. Perez // Solar Energy Materials and Solar Cells. - 2015. Vol.141. - P.7-13.

13. Dorcheh A.S., Durham R.N., Galetz M.C. Corrosion behavior of stainless and low-chromium steels and IN625 in molten nitrate salts at $600^{\circ} \mathrm{C} / /$ Solar Energy Materials and Solar Cells. - 2016. - Vol.144. - P.109-116.

14. Polarisation measurements used for corrosion rates determination / Badea G.E., Caraban A., Sebesan M., Dzitac S, Cret P., Setel A. // Journal of Sustainable Energy. - 2010. Vol.1. - No. 1. - P.16.

\section{КОРОЗІЙНИЙ ОПІР НЕРЖАВІЮЧИХ СТАЛЕЙ АІSI 304 I AISI 316 У «СОНЯЧНІЙ СОЛІ», ШО ВИКОРИСТОВУЕТЬСЯ У СОНЯЧНИХ ЕЛЕКТРОСТАНЦІЯХ: ВПЛИВ ДОМІШОК NaCl}

\section{А. Кітик, В. Проценко, В. Павлік, М. Боча}

Досліджено особливості високотемпературної корозіі нержсавіючих сталей AISI 304 і AISI 316 у розплавленій суміші, що має назву «сонячна» сіль і використовується на геліоконцентруючих електростаниіях (60 мас.\% $\mathrm{NaNO}_{3}$ та 40 мас.\% $\left.\mathrm{KNO}_{3}\right)$, при температурі $550^{\circ} \mathrm{C}$. Показано, що на швидкість корозії впливають як склад нержавіючої сталі, так і наявність домішок $\mathrm{NaCl}$ y «сонячній солі». Доведено, що зі збільшенням кониентрації домішки хлориду натрію у «сонячній солі» спостерігається пришвидшення корозії для обох марок сталі. Корозійний опір нержавіючих сталей AISI 304 і AISI 316 обумовлений формуванням $(\mathrm{Cr}, \mathrm{Fe})_{2} \mathrm{O}_{3}$ оксидної плівки на поверхні зразків. Таким чином, нержавіюча сталь AISI 304 з вмістом хрому близько 20\% показує більш високу корозійну стійкість в «сонячній солі», ніж нержавіюча сталь AISI 316 з вмістом хрому близько 18\%. Нержавіюча сталь AISI 304 характеризуеться більш високим вмістом нікелю і додатково містить молібден. Присутність цих перехідних металів в складі нержавіючої сталі також може забезпечувати утворення захисноі оксидної плівки, що запобігає подальшому корозійному руйнуванню сталевих зразків.

Ключові слова: «сонячна сіль», домішки $\mathrm{NaCl}$, корозія, нержавіюча сталь, захисна оксидна плівка, геліоконцентруючі електростанції.

\section{CORROSION RESISTANCE OF AISI 304 AND AISI 316 STAINLESS STEELS IN A SOLAR SALT USED IN CONCENTRATED SOLAR POWER PLANTS: THE EFFECT OF NaCl IMPURITIES}

\section{A. Kityk a, *, V. Protsenko ${ }^{a}$, V. Pavlik ${ }^{b}$, M. Boča ${ }^{b}$ \\ a Ukrainian State University of Chemical Technology, Dnipro, Ukraine}

b Institute of Inorganic Chemistry, Slovak Academy of Sciences, Bratislava, Slovakia

*e-mail: kitykanna7@gmail.com

High-temperature corrosion of stainless steels AISI 316 and AISI 304 in a molten «solar salt» used as a heat transfer fluid in concentrating solar power (60 wt.\% $\mathrm{NaNO}_{3}$ and $40 \mathrm{wt} . \% \mathrm{KNO}_{3}$ ) was investigated at the temperature of $550^{\circ} \mathrm{C}$. It was shown that the corrosion rate is influenced by the composition of stainless steel and the presence of impurities $\mathrm{NaCl}$ in the solar salt. With an increase in the content of sodium chloride impurity in the solar salt, the corrosion rate of both stainless steels increases. The corrosion resistance to the destruction of stainless steels AISI 316 and AISI 304 is provided by the formation of $(\mathrm{Cr}, \mathrm{Fe})_{2} \mathrm{O}_{3}$ oxide film on the surface of the samples. Thus AISI 304 stainless steel with chromium content of ca. $20 \%$ shows higher corrosion resistance in the solar salt than AISI 316 stainless steel with lower chromium content (ca. 18\%). It is known that AISI 304 stainless steel additionally contains molybdenum and a higher content of nickel. The presence of these transition metals in the composition of stainless steel also affects the formation of a protective oxide film that prevents further corrosion damage of steel samples.

Keywords: solar salt; $\mathrm{NaCl}$ impurity; corrosion; stainless steel; protective oxide film; concentrating solar power. 


\section{REFERENCES}

1. Zhang H.L., Baeyens J., Degreve J., Caceres G. Concentrated solar power plants: review and design methodology. Renewable and Sustainable Energy Reviews, 2013, vol. 22, pp. 466-481.

2. Vignarooban K., Xu X., Arvay A., Hsu K., Kannan A.M. Heat transfer fluids for concentrating solar power systems - a review. Applied Energy, 2015, vol. 146, pp. 383-396.

3. Moser M., Trieb F., Fichter T. Potential of concentrating solar power plants for the combined production of water and electricity in MENA countries. Journal of Sustainable Development of Energy, Water and Environment Systems, 2013, vol. 1, no. 2, pp. 122-140.

4. Baharoon D.A., Rahman H.A., Omar W.Z.W., Fadhl S.O. Historical development of concentrating solar power technologies to generate clean electricity efficiently - a review. Renewable and Sustainable Energy Reviews, 2015, vol. 41, pp. 996-1027.

5. Guillot S., Faik A., Rakhmatullin A., Lambert J., Veron E., Echegut P., Bessada C., Calvet N., Py X. Corrosion effects between molten salts and thermal storage material for concentrated solar power plants. Applied Energy, 2012, vol. 94, pp. 174-181.

6. Tian Y., Zhao C.Y. A review of solar collectors and thermal energy storage in solar thermal applications. Applied Energy, 2013, vol. 104, pp. 538-553.

7. Liu M., Saman W., Bruno F. Review on storage materials and thermal performance enhancement techniques for high temperature phase change thermal storage systems. Renewable and Sustainable Energy Reviews, 2012, vol. 16, pp. 2118-2132.
8. Kearney D., Kelly B., Herrmann U., Cable R., Pacheco J., Mahoney R., Price H., Blake D., Nava P., Potrovitza N. Engineering aspects of a molten salt heat transfer fluid in a trough solar field. Energy, 2004, vol. 29, pp. 861-870.

9. Kolb G.J. Economic evaluation of solar-only and hybrid power towers using molten salt technology. Solar Energy, 1998, vol. 62, pp. 51-61.

10. Singh I.B., Sen U. The effect of $\mathrm{NaCl}$ addition on the corrosion of mild steel in $\mathrm{NaNO}_{3}$ melt. Corrosion Science, 1993, vol. 34, pp. 1733-1742.

11. Fernandez A.G., Lasanta M.I., Perez F.J. Molten salt corrosion of stainless steels and low-Cr steel in CSP plants. Oxidation of Metals, 2012, vol. 78, pp. 329-348.

12. Fernandez A.G., Galleguillos H., Fuentealba E., Perez F.J. Corrosion of stainless steels and low-Cr steel in molten $\mathrm{Ca}\left(\mathrm{NO}_{3}\right)_{2}-\mathrm{NaNO}_{3}-\mathrm{KNO}_{3}$ eutectic salt for direct energy storage in CSP plants. Solar Energy Materials and Solar Cells, 2015, vol. 141, pp. 7-13.

13. Dorcheh A.S., Durham R.N., Galetz M.C. Corrosion behavior of stainless and low-chromium steels and IN625 in molten nitrate salts at $600^{\circ} \mathrm{C}$. Solar Energy Materials and Solar Cells, 2016, vol. 144, pp. 109-116.

14. Badea G.E., Caraban A., Sebesan M., Dzitac S., Cret P., Setel A. Polarisation measurements used for corrosion rates determination. Journal of Sustainable Energy, 2010, vol. 1, no. 1, pp. 16-16. 